\title{
The clinical impact of bacterial biofilms
}

\author{
Niels Høiby ${ }^{1,2 *}$, Oana Ciofu ${ }^{2}$, Helle Krogh Johansen ${ }^{1}$, Zhi-jun Song ${ }^{1}$, Claus Moser ${ }^{1}$, Peter Østrup Jensen ${ }^{1}$, Søren \\ Molin $^{3}$, Michael Givskov ${ }^{2}$, Tim Tolker-Nielsen ${ }^{2}$, Thomas Bjarnsholt ${ }^{1,2}$ \\ ${ }^{1}$ Department of Clinical Microbiology, Rigshospitalet; ${ }^{2}$ Institute for International Health, Medical Microbiology and \\ Immunology; ${ }^{3}$ BioScience and Technology, Biocentrum, Danish Technical University
}

Bacteria survive in nature by forming biofilms on surfaces and probably most, if not all, bacteria (and fungi) are capable of forming biofilms. A biofilm is a structured consortium of bacteria embedded in a self-produced polymer matrix consisting of polysaccharide, protein and extracellular DNA. Bacterial biofilms are resistant to antibiotics, disinfectant chemicals and to phagocytosis and other components of the innate and adaptive inflammatory defense system of the body. It is known, for example, that persistence of staphylococcal infections related to foreign bodies is due to biofilm formation. Likewise, chronic Pseudomonas aeruginosa lung infections in cystic fibrosis patients are caused by biofilm growing mucoid strains. Gradients of nutrients and oxygen exist from the top to the bottom of biofilms and the bacterial cells located in nutrient poor areas have decreased metabolic activity and increased doubling times. These more or less dormant cells are therefore responsible for some of the tolerance to antibiotics. Biofilm growth is associated with an increased level of mutations. Bacteria in biofilms communicate by means of molecules, which activates certain genes responsible for production of virulence factors and, to some extent, biofilm structure. This phenomenon is called quorum sensing and depends upon the concentration of the quorum sensing molecules in a certain niche, which depends on the number of the bacteria. Biofilms can be prevented by antibiotic prophylaxis or early aggressive antibiotic therapy and they can be treated by chronic suppressive antibiotic therapy. Promising strategies may include the use of compounds which can dissolve the biofilm matrix and quorum sensing inhibitors, which increases biofilm susceptibility to antibiotics and phagocytosis.

Keywords: bacterial biofilm; biofilm infection; antibiotic resistance; quorum sensing

International Journal of Oral Science (2011) 3: 55-65. doi: 10.4248/IJOS11026

\section{Introduction}

Biofilm growing bacteria cause chronic infections [1] which are characterized by persisting inflammation and tissue damage [2]. Chronic infections, including foreign body infections, are infections that 1) persist in spite of antibiotic therapy, the innate and adaptive immune system and inflammatory response of the host, and 2) in

*Correspondence: Niels Høiby

Tel: 45 35457788; Fax: 4535456412

E-mail: hoiby@hoibyniels.dk

Received 14 February 2011; Accepted 9 March 2011 contrast to colonization, are characterized by immune response and persisting pathology [3] (Table 1).

The occurrence and architecture of bacterial biofilms

Foreign body infections are characterized by biofilm growth of the responsible bacteria or fungi on the outer or inner surface of the foreign body. Biofilm growth occurs on natural surfaces such as teeth [4], heart valves (endocarditis) [5], in the lungs of cystic fibrosis (CF) patients causing chronic bronchopneumonia [2], in the middle ear in patients with chronic and secretory otitis media [6-7], in chronic rhinosinusitis [8], in chronic 
Table 1 Some general features of biofilm infections in humans compared to acute planktonic infections and superficial colonization/ normal flora on skin and mucosal membranes

\begin{tabular}{|c|c|c|c|c|}
\hline Features of biofilm infections & $\begin{array}{l}\text { Necessary condition } \\
\text { for biofilm infection }\end{array}$ & $\begin{array}{l}\text { Sufficient condition } \\
\text { for biofilm infection }\end{array}$ & $\begin{array}{l}\text { Also found in acute } \\
\text { planktonic infections }\end{array}$ & $\begin{array}{c}\text { Also found in colonization/ } \\
\text { normal flora on skin and } \\
\text { mucosal membranes }\end{array}$ \\
\hline $\begin{array}{l}\text { Aggregates of bacteria embedded } \\
\text { in a self-produced polymer matrix }\end{array}$ & Yes & Yes & No & $\mathrm{No} / \mathrm{Yes}$ \\
\hline $\begin{array}{l}\text { Tolerance to clinical relevant PK/ } \\
\text { PD dosing of antibiotics in spite } \\
\text { of susceptibility of planktonic cells }\end{array}$ & Yes & Yes & No & No/Yes \\
\hline $\begin{array}{l}\text { Tolerant to both innate and } \\
\text { adaptive immune responses }\end{array}$ & Yes & Yes & No & No/Yes-unknown (s-IgA) \\
\hline Inflammation & Yes & No & Yes & No \\
\hline Biofilm-specific antigens & $\begin{array}{l}\text { No and Yes - seldom } \\
\text { - e.g. Pseudomonas } \\
\text { aeruginosa alginate }\end{array}$ & $\begin{array}{l}\text { No and Yes -seldom } \\
\text { - e.g. Pseudomonas } \\
\text { aeruginosa alginate }\end{array}$ & No & No \\
\hline Antibody response & $\begin{array}{l}\text { Yes - after some } \\
\text { weeks }\end{array}$ & No & $\begin{array}{l}\text { Yes - after some } \\
\text { weeks }\end{array}$ & No \\
\hline Chronic infections & Yes & Yes & No & No \\
\hline Foreign body associated infections & No & Yes & $\begin{array}{l}\text { No but yes the first } \\
\text { day of infection }\end{array}$ & No \\
\hline Located on surfaces & No & No & Yes & Yes \\
\hline Localized infection & Yes & No & Yes & Yes \\
\hline $\begin{array}{l}\text { Focus for spreading or local } \\
\text { exacerbation }\end{array}$ & Yes & No & Yes & Yes \\
\hline
\end{tabular}

The bold fonts indicate biofilm specific features [3].

osteomyelitis and prosthetic joint infections [9-11], in intravenous catheters and stents [12] and in chronic wounds [13-14] (Table 2). The microbes in such biofilms are characteristically kept together by a self-produced biopolymeric matrix. The matrix contains polysaccharides, proteins and extracellular DNA originating from the microbes. Compounds from the host, e.g. immunoglobulins, may also be present and the consortium can consist of one or more species living in symbiosis [1]. This condition is called sociomicrobiology [15]. The hydrated macromolecular matrix is important since it provides structural stability and protection to the biofilm. The development of bacterial biofilms over time has been intensively studied in vitro by confocal laser scanning microscopy employing green fluorescent protein-tagged bacteria. This technique has been combined with advanced in silico image-analysis to produce 3-dimensional (3-D) images of biofilms.

As an example, Pseudomonas aeruginosa (P. aeruginosa) produce a mature biofilm in 5-7 days (Figure 1). The initial step involves planktonic (individual freely moving)
Table 2 Natural and pathogenic biofilms on human tissue and foreign bodies [3]

\begin{tabular}{lcl}
\hline $\begin{array}{c}\text { "Organ A" with } \\
\text { normal flora }\end{array}$ & $\begin{array}{c}\text { Connection via } \\
\text { foreign bodies }\end{array}$ & $\begin{array}{c}\text { "Organ B" without } \\
\text { normal flora }\end{array}$ \\
\hline Skin & $\rightarrow$ & $\begin{array}{l}\text { blood, peritoneum, } \\
\text { middle ear }\end{array}$ \\
Mouth & $\rightarrow$ & teeth \\
Pharynx & $\rightarrow$ & bronchi, lungs \\
Duodenum & $\rightarrow$ & bile tract, pancreas \\
Urethra & $\rightarrow$ & urine bladder \\
Vagina & $\rightarrow$ & uterus \\
"Air in operation & $\rightarrow$ & alloplastic, \\
room" & & cerebrospinal shunt \\
\hline No symptoms & $\rightarrow$ & pathology \\
\hline
\end{tabular}

*most frequently coagulase negative staphylococci, which occur as biofilms on detached epidermal cells.

bacteria attaching reversibly to a surface, e.g. a tooth surface conditioned with a layer of proteins (a pellicle). 
The bacteria are still susceptible to antibiotics at this stage which may explain the success of the antibiotic prophylaxis for alloplastic surgery. The next step is irreversible binding to the surface, multiplication of the bacteria and microcolony formation, and production of a polymer matrix around the microcolony. The biofilm becomes thick (up to $50 \mu \mathrm{m}$ ) and mushroom-like or tower-like structures are often observed as a characteristic feature of the mature in vitro biofilm. The subsequent biofilm stage involves focal dissolution, liberating bacterial cells that can then spread to other locations where new biofilms can be formed. This liberation process may be caused by bacteriophage activity within the biofilm [16]. The mature biofilm matrix may contain water-filled channels and thereby resemble primitive, multicellular organisms. Motile bacteria can use type-IV pili to mount or climb a biofilm formed by other bacteria and colonize the top of the biofilm, resembling a hat [17].

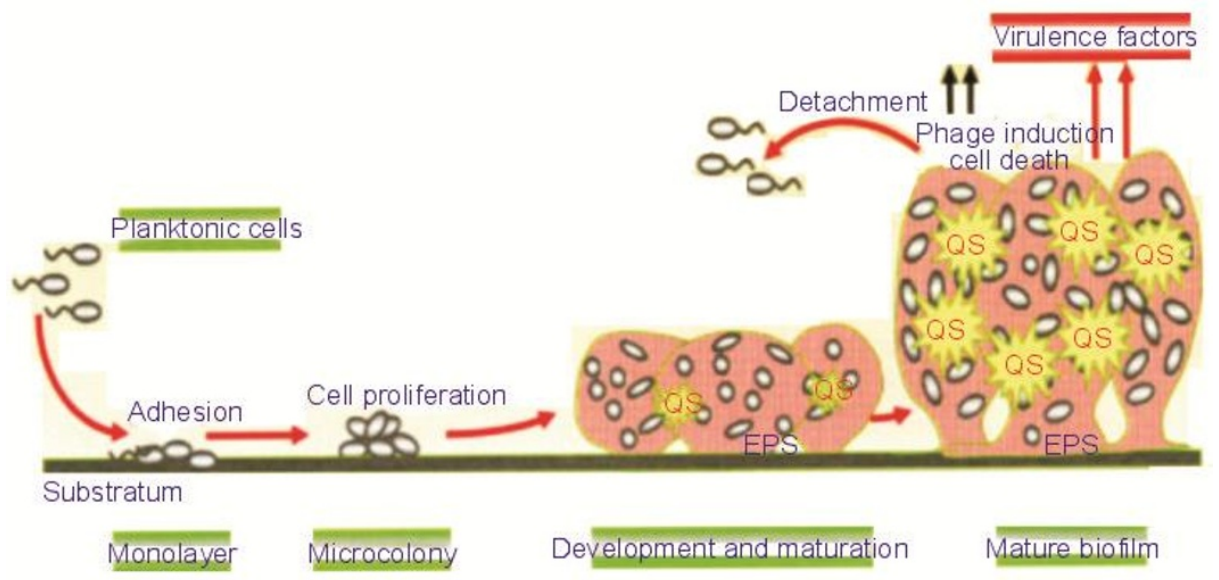

Figure 1 Time-course of formation of a $P$. aeruginosa biofilm based on in vitro experiments with green fluorescent protein-tagged $P$. aeruginosa, which grow in a flow-cell and are examined with a confocal scanning laser microscope. QS indicates cell-to-cell communication and EPS is hydrated extraclellular biofilm matrix. The thickness of the biofilm varies between $25-100 \mu \mathrm{m}$ and is determined by the balance between growth and liberation of the bacteria. Reproduced from [57] with permission.

Important properties of bacteria in biofilms are different in planktonic bacteria and this has significant diagnostic and therapeutic consequences:

A) The bacteria appear different in biofilm infections since they are located close to each other and surrounded by self-produced matrix. A biofilm can often be recognized by light microscopy although precise identification of all the bacteria within a biofilm can only be done by DNA hybridization techniques. Identification of the components of the biofilm matrix requires specialized staining techniques. Some results, however, indicate that biofilm-specific antibodies develop and can be used as diagnostics [3, 18]. This is important, since ordinary sampling techniques may not be sufficient to detect biofilm growing bacteria unless the bacteria are released by ultrasonic treatment [19-20].

B) Transcriptomic studies of global gene-expression in $P$. aeruginosa biofilms indicate adaptation of both physiology and biochemistry of biofilm growing bacteria compared to planktonic growing bacteria [21-22]. When the pattern of gene expression during biofilm growth is investigated, the results indicate that the bacterial cells mostly resemble planktonically growing bacteria in the stationary growth phase in which bacteria exhibit low metabolic activity. Furthermore, there is upregulation of genes which are necessary for anaerobic growth [21]. Probing with microelectrodes has shown that the bottom of a biofilm is anaerobic and that little bacterial growth and metabolic activity occurs there. In contrast, the conditions at the surface of the biofilm are aerobic and allow more growth and metabolic activity [23-24]. Gradients, therefore, characterize biofilms. These physiological conditions may partly explain the resistance of biofilm growing bacteria to antimicrobial therapy [3]. 
C) Biofilm growing bacteria exhibit increased tolerance against antibiotics, disinfectants, and innate and adaptive host immune mechanisms. The minimal inhibitory concentration (MIC) and minimal bactericidal concentration $(\mathrm{MBC})$ of antibiotics to biofilm growing bacteria may be up to 100-1 000 fold higher than that of planktonic bacteria. Methods to test antibiotic susceptibility of biofilm growing bacteria have therefore been developed [3], but their clinical relevance with regard to prediction of successful clinical therapy has been disappointing [25]. The molecular mechanisms responsible for resistance are a mixture of conventional resistance mechanisms, which also protect planktonic growing bacteria and the specific properties of biofilms that increase the tolerance of the bacteria against antibiotics [3]. The conventional resistance mechanisms to betalactam antibiotics and colistin have been most thoroughly studied in P. aeruginosa biofilms where the resistance mechanisms are induced when the biofilm is exposed to these two classes of antibiotics $[3,26]$. The response of the biofilm is the production of increased amounts of chromosomal beta-lactamase which degrade beta-lactam antibiotics [3], or the production of a modified lipopolysaccharide, which makes the bacteria resistant to colistin [3, 27]. These conventional resistance mechanisms are coupled with stationary-phase physiology, slow growth in the center of the biofilm, and possible matrix mediated antibiotic binding and diffusion retardation. The overall result may at least partially explain the resistance of biofilms and, by extension, the characteristic persistence and recurrence of the clinical signs of inflammation in cases of antibiotic treated biofilm infections [3] (Figure 2).

D) Accordingly, biofilm-growing bacteria cause chronic infections and persisting inflammation and tissue damage i.e. they cause disease $[3,28]$.

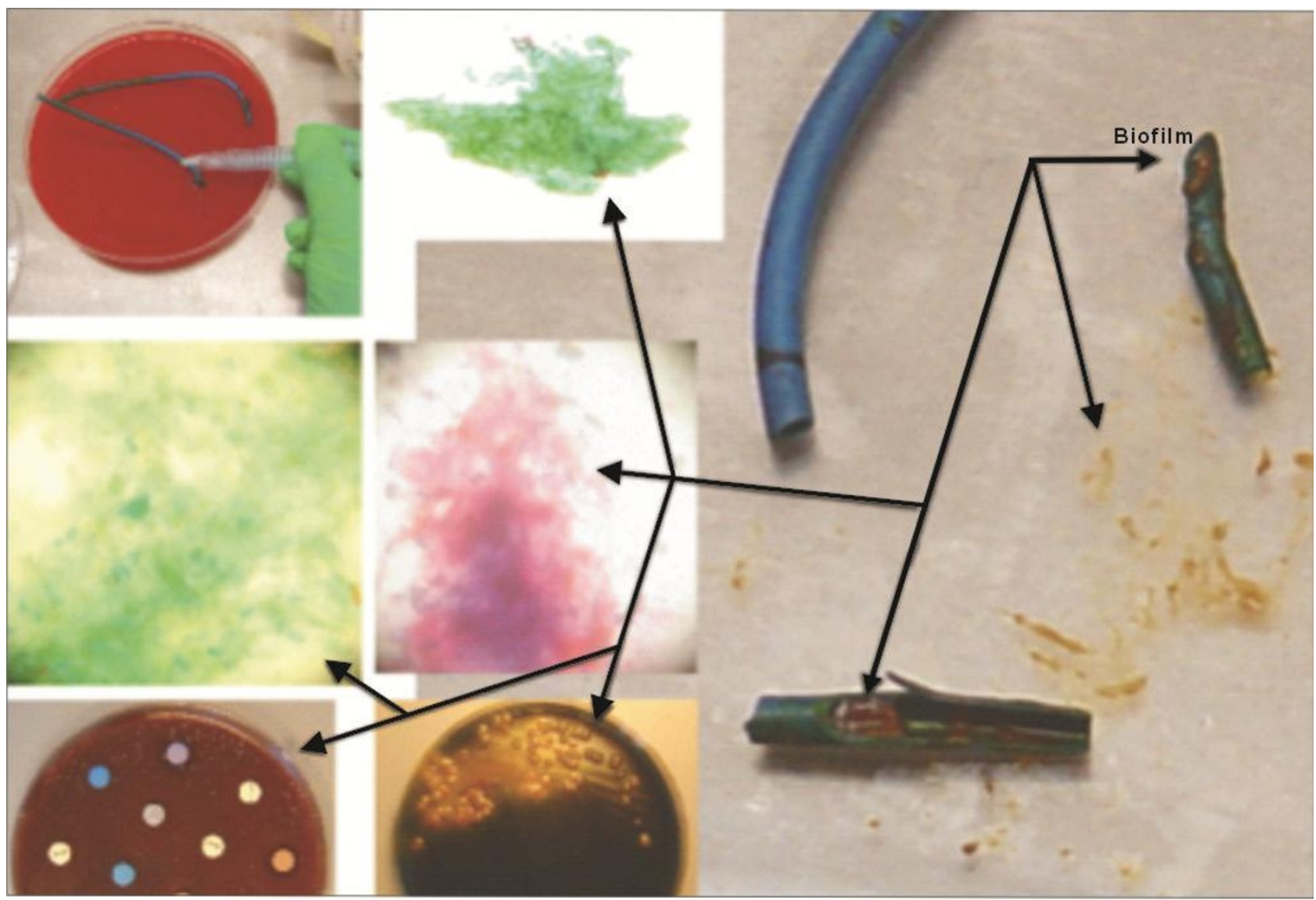

Figure 2 Example of a biofilm on a biliary stent which became the focus of repeated incidents of ultimately fatal sepsis. DNA typing (pulsed field gel electrophoresis) showed that the same clonal type of $E$. coli was present in both the biofilm and the blood. In spite of relevant antibiotic therapy, it was not possible to eradicate the biliary focus on the stent and the second incident of sepsis was fatal. Microphotos: Gram and methylene blue staining, magnification $\times 100$ and $\times 1000$ [3]. 


\section{Prophylaxis and treatment of $P$. aeruginosa biofilms in CF lungs - perspectives for other biofilm infections?}

$\mathrm{CF}$ is a congenital, recessively inherited disorder which affects one out of 2000 newborns in Caucasian populations. If not treated, most $\mathrm{CF}$ patients die at a young age. If intensively treated, the mean expected lifetime is $>35$ years and in some centres $>50$ years. The genetic etiology involves one of $>1500$ potential mutations in the cystic fibrosis transmembrane conductance regulator gene (CFTR) on chromosome 7 , resulting in malfunction of the chloride channel in CF patients. The malfunction of the chloride channel in CF patients leads to decreased volume of the paraciliary fluid in the lower respiratory tract, and that in turn leads to impaired mucociliary clearance of inhaled microbes [29]. This impairment of the non-inflammatory defense mechanism of the respiratory tract leads to early recruitment of the inflammatory defense mechanisms e.g. polymorphonuclear leukocytes (PMN) and antibodies [30-32]. Therefore, starting at early childhood, CF patients suffer from recurrent and chronic respiratory tract infections characterized by PMN mediated inflammation. In spite of the inflammatory response and intensive antibiotic therapy, however, infections caused by e.g. P. aeruginosa persist and lead to respiratory failure and lung transplantation or death of the patients [33]. Previously, $50 \%$ of CF patients would succumb within 5 years after onset of the chronic $P$. aeruginosa infection, but intensive early eradication therapy has completely changed the prognosis and most patients will not contract the chronic infection during childhood anymore [34].

Adaptive mechanisms of $P$. aeruginosa exist which explain why this pathogen is able to survive and persist for several decades in the respiratory tract of CF patients, in spite of the defense mechanisms of the host and intensive antibiotic therapy. P. aeruginosa is able to survive by switching to the biofilm mode of growth (Figures 3, 4), which provides tolerance to the inflammatory defense mechanism and antibiotic therapy. Biofilm adaptation also allows survival in the aerobic respiratory zone, the conductive zone of the lungs which contain anaerobic sputum, and the paranasal sinuses where the mucus also has a decreased oxygen concentration [2-3, 35-40]. During the adaptation, mucoid (biofilm mode of growth) and non-mucoid phenotypes are split off due to mutations (Figure 5, Table 3).

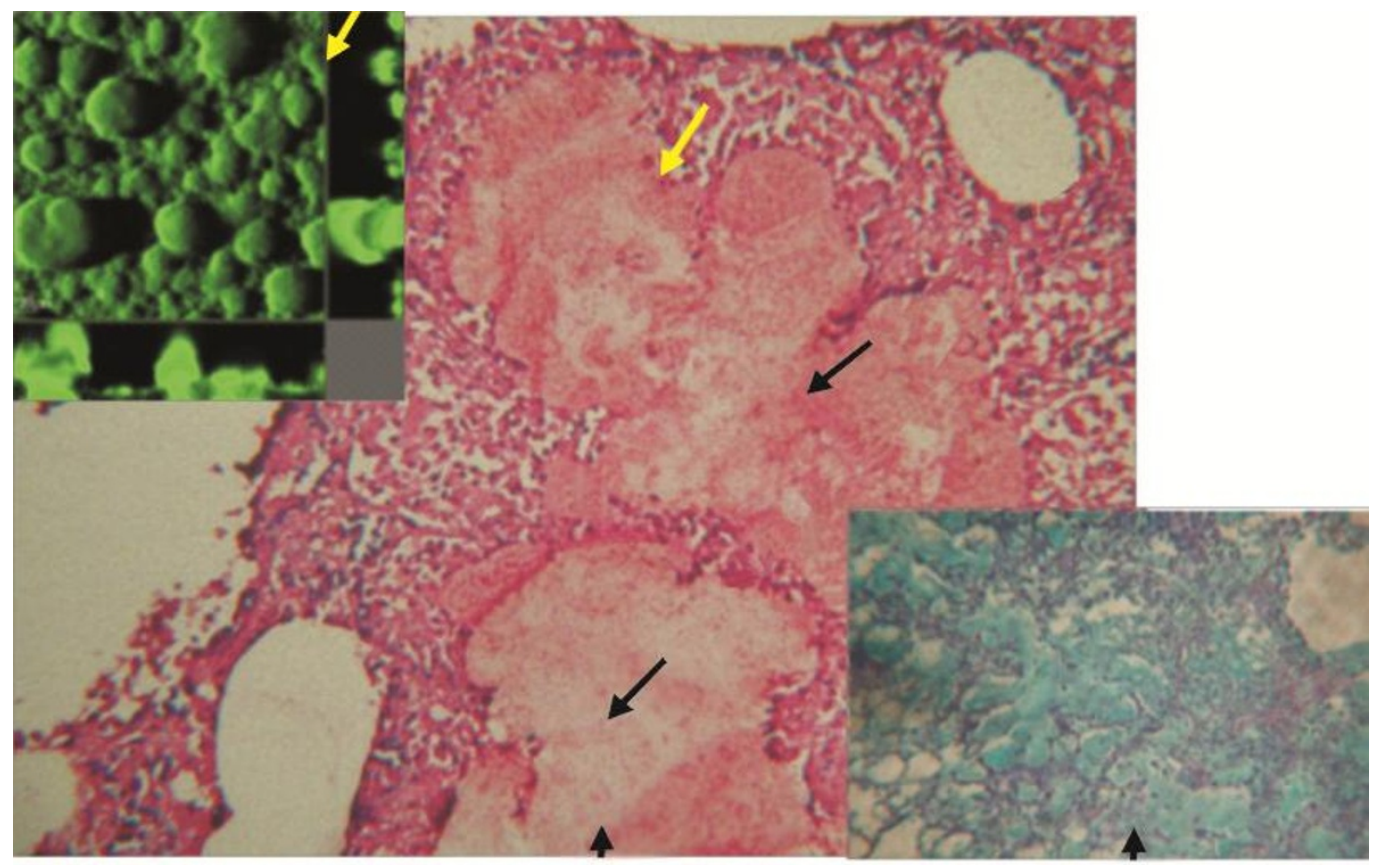

Figure 3 Biofilms of $P$. aeruginosa grown in vitro in a flow cell (left upper panel, green fluorecent protein-tagged bacteria studied by confocal laser scanning microscopy, top view and 2 side views), in vivo in a CF mouse (right lower panel, alcian blue stained CF mouse lung [37]) and in vivo in the lungs of a CF patient who died of chronic lung infection (center panel, hematoxylen-eosin stained). The arrows indicate the biofilms in all three panels [39]. 


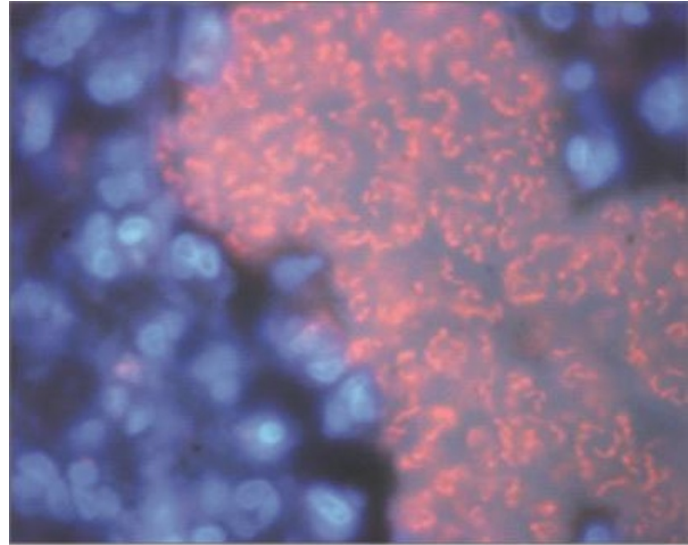

Figure 4 FISH staining (fluorescent in situ hybridization: red colored bacteria due to fluorescein-labelled peptide nucleic acid specific for $P$. aeruginosa) of $P$. aeruginosa in a biofilm from an explanted lung of a CF patient with chronic lung infection. The surrounding PMNs are stained blue (the nuclei) by 4',6-diamidino-2-phenylindole (DAPI) [39].

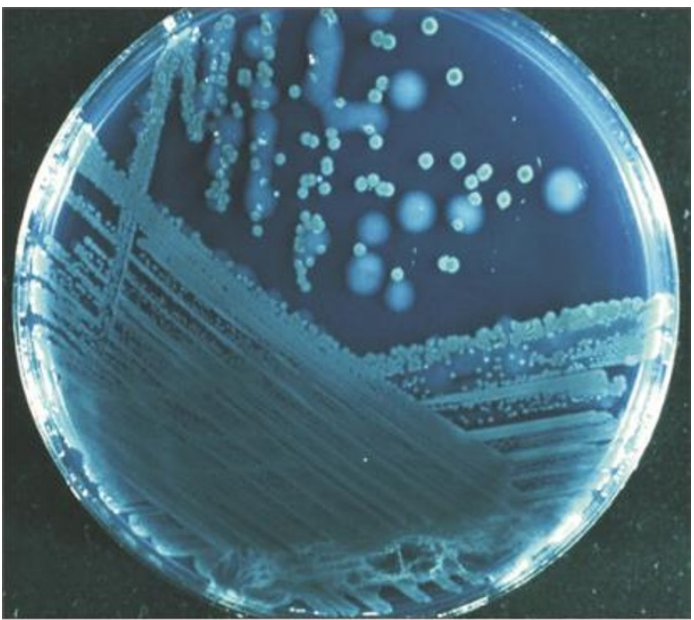

Figure 5 Growth of mucoid (large) and non-mucoid (small) colonies of $P$. aeruginosa from sputum of a CF patient with chronic biofilm lung infection [39].

Table 3 Important properties of mucoid and non-mucoid phenotypes of $P$. aeruginosa in the respiratory tract of cystic fibrosis patients $[2,39]$

\begin{tabular}{lll}
\hline \multicolumn{1}{c}{ Properties } & \multicolumn{1}{c}{ Mucoid phenotype } & \multicolumn{1}{c}{ Nonmucoid phenotype } \\
\hline Location in the lungs & $\begin{array}{l}\text { Respiratory zone and conductive } \\
\text { zone in sputum }\end{array}$ & Conductive zone in sputum \\
Biofilm formation in vitro & Yes & Yes \\
Biofilm formation in vivo & Yes & No \\
$\begin{array}{l}\text { Multiplied antibiotic resistance due to conventional } \\
\text { mechanisms }\end{array}$ & Seldom & Frequent \\
Resistance due to biofilm properties & Yes & No \\
Responsible for lung tissue damage & Yes & No \\
Induce pronounced antibody response & Yes & No \\
\hline
\end{tabular}

The currently used methods for preventing chronic $P$. aeruginosa biofilms in CF lungs are 1) prevention of cross-infection from other already chronically infected $\mathrm{CF}$ patients by isolation techniques and hygienic measures [41], 2) early aggressive eradication therapy of intermittent colonization by means of oral ciprofloxacin and nebulized colistin for 3 weeks (even 3 months) or by using nebulized tobramycin as monotherapy [42], or 3) daily nebulized DNase (Pulmozyme) [43]. These 3 methods, which are combined in most CF centers, are successful, cost-efficient and have completely changed the epidemiology of chronic $P$. aeruginosa lung infections in CF patients from being very common in $\mathrm{CF}$ children to being predominantly a problem for adult patients. No problems of resistance to the antibiotics have been recorded in intermittently colonized CF patients [34, 44-45]. Early aggressive eradication therapy has also been shown to be efficient in a $\mathrm{CF}$ animal model of $P$. aeruginosa infection [46]. Furthermore, although vaccines against $P$. aeruginosa have been developed and undergone clinical trials, they have not been further developed due to the success of the early, aggressive eradication therapy [47].

The recommended method for treatment of chronic $P$. aeruginosa biofilm infection is chronic suppressive antibiotic therapy $[2,48]$ that is started when the chronic infection is diagnosed (continuous colonization at the monthly bacteriological examinations for 6 months and/ 
or increased level of antibodies against $P$. aeruginosa) [49]. The chronic suppressive therapy consists of daily nebulized colistin or tobramycin for the rest of the patient's life combined with either regular 2-week courses every 3 months of intravenous anti-pseudomonas antibiotics (combination therapy of 2 antibiotics: tobramycin or colistin + ceftazidime, or piperacillin/tazobactam, or carbapenem, or aztreonam, or ciprofloxacin) or ad hoc intravenous therapy when clinical manifestations occur [48]. Additionally, DNase is inhaled every day to reduce the viscosity of the DNA-containing sputum [43] and daily oral azithromycin is given to the patients as mentioned below [50]. Chronic suppressive therapy (maintenance therapy) successfully maintains, or at least slows the decline of pulmonary function and prolongs the life of patients for many years [51]. The side-effects of the maintenance therapy can include high levels of conventional resistance in the persisting strains and high levels of allergies to the beta-lactam antibiotics [52-53]. Similar principles as used in CF patients are gradually being introduced in other areas of biofilm infection treatment $[10-11,54]$ : a) systemic or local prophylactic use of antibiotics to prevent biofilm formation, b) early aggressive eradication therapy to eradicate planktonic growth or early biofilm formation and c) chronic suppressive antibiotic therapy to maintain the function of inserted foreign bodies etc.

\section{Quorum sensing}

Both the ability to grow as a biofilm and the ability to communicate with specific signal molecules are probably common among most bacterial species [55-56]. Bacteria communicate by means of synthesizing and reacting to signal molecules. Quorum sensing (QS) allows bacteria to sense the concentration of other bacteria present within a limited microenvironment and respond by activating certain genes which then produce e.g. virulence factors such as enzymes or toxins. These QS molecules can be peptides in many Gram-positive bacteria whereas the most well-described QS molecules in Gram-negative bacteria are N-acyl-L-homoserine lactones (AHL) [55, 57]. QS is also found in biofilm forming fungi such as Aspergillus species and Candida albicans where the alcohols farnesol and tyrosol are QS molecules that can influence morphology etc. [58-61]. The classical example of QS is activation of bioluminescence (light production) in Vibrio fischeri, and most of the AHL-producing bacteria are related to higher organisms such as plants and animals, where they act as symbionts or pathogens [55, 57]. Examples include the human pathogens $P$. aeruginosa, Yersinia enterocolitica and Brucella melitensis. AHL is synthesized by synthase proteins (I) and cooperates with transcriptional regulator proteins $(\mathrm{R})$ to regulate the expression of specific genes which e.g. in P. aeruginosa control the production of virulence factors such as extracellular enzymes and cellular lysins (e.g. rhamnolipid), which are important for the pathogenesis of infections [62]. Bacteria, therefore, are not fully armed pathogens until they reach the number/concentration where the QS system activates the production of the virulence factors. These bacteria are merely innocent colonizers until the QS is activated. QS may also have influence on the development of biofilms [63]. QS has been shown to determine the tolerance of $P$. aeruginosa biofilms to antibiotic therapy and innate inflammatory responses dominated by polymorphonuclear leucocytes [62, 64-65].

\section{Quorum sensing inhibitors (QSI)}

Much of our knowledge about QS originates from experiments with QS knock-out mutants and from use of naturally occurring and artificially synthesized quorum sensing inhibitors (QSI) [57]. It was observed that certain sea-weed plants never became covered with bacteria or higher organisms (called biofouling, which also occurs on submerged surfaces of ships) because the plant produced halogenated furanones, which have QSI activity [66]. Large-scale screening for QSIs in nature was therefore performed. This process has been simplified with the use of gene-manipulated bacteria that can only grow if a QSI is present in the substrate [67]. These naturally occurring QSI compounds can be synthesized and their structures modified to inhibit QS in vivo in experimental animal infections [68]. Since it has been shown that bacteria causing experimental animal infections actually communicate in vivo [69], a phenomenon that is likely occurring in CF patients with chronic $P$. aeruginosa lung infections [70], some interesting clinical possibilities arise. If such QSIs are free of toxic side effects, they may be used to treat biofilm infections like chronic $P$. aeruginosa lung infections [71]. Interestingly, some antibiotics, like ceftazidime and ciprofloxacin and the macrolides azithromycin and clarithromycin [72], inhibit QS in P. aeruginosa at sub-MIC concentrations leading to inhibition of the virulence of these bacteria. However, azithromycin and clarithromycin, in contrast with ciprofloxacin and ceftazidime, cannot inhibit bacterial growth at obtainable concentrations in vivo. Controlled clinical trials using azithromycin to treat the chronic $P$. aeruginosa lung infection in both CF children and adults have shown significant improvement in lung function [73-74]. Most CF patients with chronic $P$. aeruginosa lung infections are therefore now treated 
continuously with azithromycin [50]. An expected side effect has, however, been the development of resistance to macrolides in other pathogenic bacteria, like $S$. aureus, in CF patients [75]. It would therefore be desirable to use QSIs without conventional growth-inhibiting or bactericidal activity, and accordingly is now a focus of current research [56]. Examples of such naturally occurring QSI are found in ginseng [26] and garlic extracts, and can sensitize otherwise resistant $P$. aeruginosa biofilms to antibiotic therapy and to PMN activity. The consequence of these QSIs is, more or less, eradication of the biofilm via antibiotic therapy and PMN activity, which dominates the inflammatory response in $\mathrm{CF}$ patients (Figure 6) [64-65]. Some clinical effects in CF patients have also been reported [76]. According to current knowledge, QSI resistance can only occur due to mutations that render the QS deficient bacteria unable to produce virulence factors [77], i.e. the bacteria become non-virulent. Such mutations have been found to occur during chronic $P$. aeruginosa lung infections in $\mathrm{CF}$ patients [78] when the bacteria change to the "chronic phenotype" and lose their ability to make virulence factors.

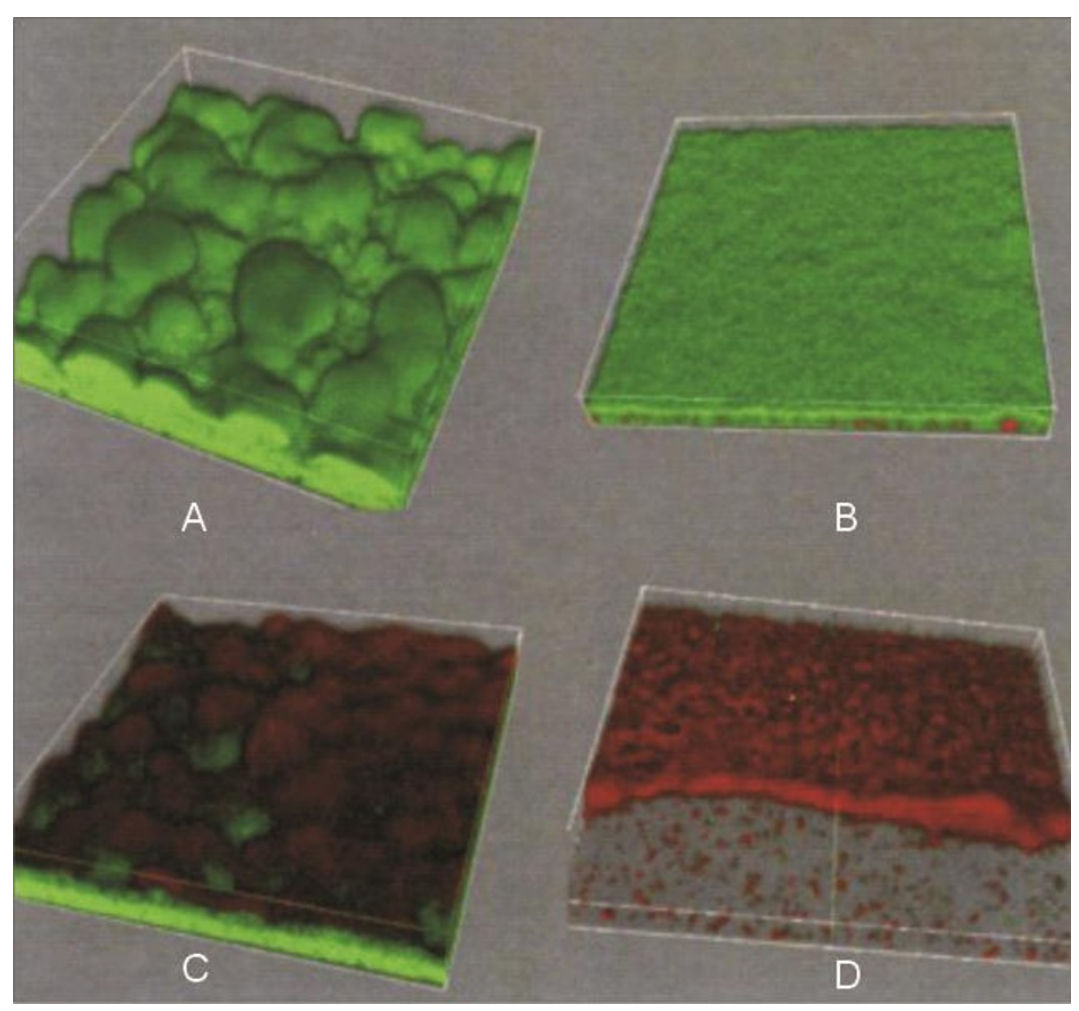

Figure $6 \mathrm{~A}$ four-day-old biofilm formed by green fluorescent protein-tagged $P$. aeruginosa cultured in the absence (A and $\mathbf{B}$ ) or presence (C and $\mathbf{D}$ ) of $2 \%$ garlic extract. The biofilms $\mathbf{B}$ and $\mathbf{D}$ were treated on day $3 \mathrm{with} 340 \mu \mathrm{g} \cdot \mathrm{mL}^{-1}$ tobramycin for $24 \mathrm{~h}$. The biofilms were then stained with LIVE/DEAD BacLight bacterial Viability Kit, where dead bacteria are red and living bacteria are green. It is seen that in the presence of garlic extract, tobramycin can kill the bacteria in the biofilm whereas they survive if tobramycin or garlic is used alone. Reproduced from [65] with permission.

\section{Conventional drugs and QSI for prevention and treatment of foreign body infections}

Foreign body infections constitute a steadily increasing medical problem and can occur on intravenous catheters, intrauterine catheters, naso-laryngeal tubes, stents (Figure 2), alloplastic materials, hydrocephalus shunts and arti- ficial hearts [79]. If such alloplastic materials become colonized with biofilm-forming bacteria, the result is most often chronic inflammation around the foreign body which either has to be replaced or treated with sometimes lifelong antibiotic suppressive therapy; although, careful choice of antibiotics and early therapy may sometimes lead to eradication of the condition. Antibiotic covered 
foreign bodies, e.g. catheters, and vascular proteases have been used to prevent biofilm formation and have been shown to be quite efficient $[54,80]$. It would, however, be better to develop other compounds due to the risk of development of bacterial resistance and allergic reactions to the antibiotics. Therefore, QSIs are good candidates. QSIs have been shown to synergize with the weak effects of antibiotics and PMNs on biofilm growing bacteria in vitro and in vivo in animal experiments, resulting in biofilm elimination (Figure 6) $[62,65]$. These promising results have lead to further development of QSIs as pharmaceutical compounds for patients who are subject to implantation of foreign bodies. Disruption of the biofilm matrix by e.g. alginate lyase, F-actin or DNase has also been used in experimental studies [81]. Such approaches, if successful, will have large, positive consequences for invasive medical treatment.

In conclusion, our increasing knowledge about the nature and properties of biofilm growing bacteria is the basis for efficient prophylaxis, diagnosis (Table 1) and treatment of chronic biofilm infections. The current methods that are used, however, are not yet sufficient. Further progress will undoubtedly rely on comprehensive efforts in basic, applied and clinical research.

\section{References}

1 Costerton W, Veeh R, Shirtliff M, et al. The application of biofilm science to the study and control of chronic bacterial infections. J Clin Invest 2003; 112: 1466-1477.

2 Bjarnsholt T, Jensen PØ, Fiandaca MJ, et al. Pseudomonas aeruginosa biofilms in the respiratory tract of cystic fibrosis patients. Pediatr Pulmonol 2009; 44: 547-558.

3 Høiby N, Bjarnsholt T, Givskov M, Molin S, Ciofu O. Antibiotic resistance of bacterial biofilms. Int $J$ Antimicrob Agents 2010; 35: 322-332.

4 Palmer RJ, Darveau R, Lamont RJ, Nyvad B, Teles RP. Human oral bacterial biofilms: composition, dynamics, and pathogenesis. In: Bjarnsholt T, Moser C, Jensen PØ, Høiby N, eds. Biofilm infections. New York: Springer, 2010: 35-68.

5 Høiby N, Döring G, Schiøtz PO. The role of immune complexes in the pathogenesis of bacterial infections. Annu Rev Microbiol 1986; 40: 29-53.

6 Hall-Stoodley L, Hu FZ, Gieseke A, et al. Direct detection of bacterial biofilms on the middle-ear mucosa of children with chronic otitis media. JAMA 2006; 296: 202-211.

7 Homøe P, Bjarnsholt T, Wessman M, Sørensen H C, Johansen HK. Morphological evidence of biofilm formation in Greenlanders with chronic suppurative otitis media. Eur Arch Otorhinolaryngol 2009; 266: 1533-1538.
8 Sanderson AR, Leid JG, Hunsaker D. Bacterial biofilms on the sinus mucosa of human subjects with chronic rhinosinusitis. Laryngoscope 2006; 116: 1121-1126.

9 Gristina AG, Oga M, Webb LX, Hobgood CD. Adherent bacterial colonization in the pathogenesis of osteomyelitis. Science 1985; 228: 990-993.

10 Trampuz A, Zimmerli W. Prostetic joint infections: update in diagnosis and treatment. Swiss Med Wkly 2005; 135: 243 251.

11 Del Pozo JL, Patel R. Infection associated with prosthetic joints. N Engl J Med 2009; 361: 787-794.

12 Tacconelli E, Smith G, Hieke K, Lafuma A, Bastide P. Epidemiology, medical outcomes and costs of catheterrelated bloodstream infection in intensive care units of four European countries: litterature- and registry-based estimates. $J$ Hosp Infect 2009; 72: 97-103.

13 Kirketerp-Møller K, Jensen PØ, Fazli M, et al. Distribution, and ecology of bacteria in chronic wounds. J Clin Microbiol 2008; 46: 2717-2722.

14 Bjarnsholt T, Kirketerp-Møller K, Jensen PØ, et al. Why chronic wounds will not heal: a novel hypothesis. Wound Repair Regen 2008; 16: 2-10.

15 Parsek MR, Greenberg EP. Sociomicrobiology: the connections between quorum sensing and biofilms. Trends Microbiol 2005; 13: 27-33.

16 Webb JS, Givskov M, Kjelleberg S. Bacterial biofilms: prokaryotic adventures in multicellularity. Curr Opin Microbiol 2003; 6: 578-585.

17 Klausen M, Heydorn A, Ragas P, et al. Biofilm formation by Pseudomonas aeruginosa wild type, flagella and type IV pili mutants. Mol Microbiol 2003; 48: 1511-1524.

18 Brady RA, Leid JG, Camper AK, Costerton JW, Shirtliff ME. Identification of Staphylococcus aureus proteins recognized by the antibody-mediated immune response to a biofilm infection. Infect Immun 2006; 74: 3415-3426.

19 Kobayashi N, Bauer TW, Tuohy MJ, Fujishiro T, Procop GW. Brief ultrasonication improves detection of biofilmformative bacteria around a metal implant. Clin Orthop Relat Res 2007; 475: 210-213.

20 Ensing GT, Neut D, van Horn JR, van der Mei HC, Busscher HJ. The combination of ultrasound with antibiotics released from bone cement decreases the viability of planktonic and biofilm bacteria: an in vitro study with clinical strains. J Antimicrob Chemother 2006; 58: 1287-1290.

21 Hentzer M, Eberl L, Givskov M. Transcriptome analysis of Pseudomonas aeruginosa biofilm developemnt: anaerobic respiration and iron limitation. Biofilms 2005; 2: 37-61.

22 Lee B, Schjerling CK, Kirkby N, et al. Mucoid Pseudomonas aeruginosa isolates maintain the biofilm formation capacity and the gene expression profiles during the chronic lung infection of CF patients. APMIS 2011. Electrongic: DOI 10.1111/j.1600-0463.2011.02726.x 
23 Costerton JW, Lewandowski Z, Caldwell DE, Korber DR, Lappinscott HM. Microbial biofilms. Annu Rev Microbiol 1995; 49: 711-745.

24 Werner E, Roe F, Bugnicourt A, et al. Stratified growth in Pseudomonas aeruginosa biofilms. Appl Environ Microbiol 2004; 70: 6188-6196.

25 Moskowitz SM, WEmerson JC, McNamara S, et al. Randomized trial of biofilm testing to select antibiotics for cystic fibrosis airway infection. Pediatr Pulmonol 2011; 46: 184-192.

26 Herrmann G, Yang L, Wu H, et al. Colistin-tobramycin combinations are superior to monotherapy concerning killing of biofilm Pseudomonas aeruginosa. J Infect Dis 2010; 202: 1585-1592.

27 Johansen HK, Moskowitz SM, Ciofu O, Pressler T, Høiby N. Spread of colistin-resistant non-mucoid Pseudomonas aeruginosa among chronically infected Danish cystic fibrosis patients. J Cyst Fibros 2008; 7: 391-397.

28 Bjarnsholt T, Moser C, Jensen PØ, Høiby NE. Biofilm Infections. New York: Springer, 2010.

29 Boucher RC. New concepts of the pathogenesis of cystic fibrosis lung disease. Eur Respir J 2004; 23: 146-158.

30 Høiby N, Krogh Johansen H, Moser C, et al. Pseudomonas aeruginosa and the in vitro and in vivo biofilm mode of growth. Microbes Infect 2001; 3: 23-35.

31 Armstrong DS, Grimwood K, Carzino R, et al. Lower respiratory infection and inflammation in infants with newly diagnosed cystic fibrosis. $\mathrm{Br}$ Med J 1995; 310: 1571-1572.

32 Armstrong DS, Hook SM, Jamsen KM, et al. Lower airway inflammation in infants with cystic fibrosis detected by newborn screening. Pediatr Pulmonol 2005; 40: 500-510.

33 Høiby N, Pressler T. Emerging patogens in cystic fibrosis. In: Webb AK, Ratjen F, eds. European respiratory monograph in cystic fibrosis. London: European Respiratory Society, 2006: 66-78.

34 Hansen CR, Pressler T, Høiby N. Early aggressive eradication therapy for intermittent Pseudomonas aeruginosa airway colonization in cystic fibrosis patients: 15 years experience. J Cyst Fibros 2008; 7: 523-530.

35 Worlitzsch D, Tarran R, Ulrich M, et al. Effects of reduced mucus oxygen concentration in airway Pseudomonas infections of cystic fibrosis patients. J Clin Invest 2002; 109: 317-325.

36 Kolpen M, Hansen CR, Bjarnsholt T, et al. Polymorphonuclear leukocytes consume ooxygen in sputum from chronic Pseudomonas aeruginosa pneumonia in cystic fibrosis. Thorax 2010; 65: 57-62.

37 Hoffmann N, Rasmussen TB, Jensen PØ, et al. Novel mouse model of chronic Pseudomonas aeruginosa lung infection mimicking cystic fibrosis. Infect Immun 2005; 73: 2504-2514.

38 Jelsbak L, Johansen HK, Frost AL, et al. Molecular epidemiology and dynamics of Pseudomonas aeruginosa populations in lungs of cystic fibrosis patients. Infect Immun 2007; 75: 2214-2224.
39 Høiby N, Ciofu O, Bjarnsholt T. Pseudomonas aeruginosa biofilms in cystic fibrosis. Future Microbiol 2010; 5: 1663 1674.

40 Aasnaes K, Rickelt LF, Johansen HK, et al. Decreased mucosal oxygen tension in the maxillary sinuses in patients with cystic fibrosis. J Cyst Fibros 2011; 10: 1-7.

41 Høiby N, Pedersen SS. Estimated risk of cross-infection with Pseudomonas aeruginosa in Danish cystic fibrosis patients. Acta Paediatr Scand 1989; 78: 395-404.

42 Döring G, Høiby N. Early intervention and prevention of lung disease in cystic fibrosis: a European consensus. J Cyst Fibros 2004; 3: 67-91.

43 Frederiksen B, Pressler T, Hansen A, Koch C, Høiby N. Effect of aerosolized rhDNase (pulmozyme) on pulmonary colonization in patients with cystic fibrosis. Acta Paediatr 2006; 95: 1070-1074.

44 Baumann U, Stocklossa C, Greiner W, et al. Cost of care and clinical condition in paediatric cystic fibrosis patients. $J$ Cyst Fibros 2003; 2: 84-90.

45 Frederiksen B, Koch C, Høiby N. The changing epidemiology of Pseudomonas aeruginosa infection in Danish cystic fibrosis patients, 1974-1995. Pediatr Pulmonol 1999; 28: $159-166$.

46 van Gennip M, Moser C, Christensen LD, et al. Augmented effect of early antibiotic therapy in mice with experimental lung infections due to sequentially adapted mucoid strains of Pseudomonas aeruginosa. J Antimicrob Chemother 2009; 64: $1241-1250$

47 Döring G, Pier GB. Vaccines and immunotherapy against Pseudomonas aeruginosa. Vaccine 2008; 26: 1011-1124.

48 Döring G, Conway SP, Heijerman GM, et al. Antibiotic therapy against Pseudomonas aeruginosa in cystic fibrosis: a European consensus. Eur Respir J 2000; 16: 749-767.

49 Høiby N, Flensborg EW, Beck B, et al. Pseudomonas aeruginosa infection in cystic fibrosis. Diagnostic and prognostic significance of Pseudomonas aeruginosa precipitins determined by means of crossed immunoelectrophoresis. Scand J Respir Dis 1977; 58: 65-79.

50 Hansen CR, Pressler T, Koch C, Høiby N. Long-term azithromycin treatment of cystic fibrosis patients with chronic P. aeruginosa infection; an observational cohort study. J Cyst Fibros 2005; 4: 35-40.

51 Frederiksen B, Lanng S, Koch C, Høiby N. Improved survival in the Danish cystic fibrosis centre: results of aggressive treatment. Pediatr Pulmonol 1996; 21: 153-158.

52 Koch C, Hjelt K, Pedersen SS, et al. Retrospective clinical study of hypersensitivity reactions to aztreonam and six other beta-lactam antibiotics in cystic fibrosis patients receiving multiple treatment courses. Rev Infect Dis 1991; 13: S608-S611.

53 Ciofu O, Giwercman B, Pedersen SS, Hoiby N. Development of antibiotic resistance in Pseudomonas aeruginosa during 
two decades of antipseudomonal treatment at the Danish CF center. APMIS 1994; 102: 674-680.

54 Stensballe J, Tvede M, Loorns D, et al. Infection risk with nitrofurazone-impregnated urinary catheters in trauma patients. Ann Intern Med 2007; 147: 285-293.

55 Fuqua C, Parsek MR, Greenberg EP. Regulation of gene expression by cell-to-cell communication: acyl-homoserine lactone quorum sensing. Annu Rev Genet 2001; 35: 439468.

56 Bjarnsholt T, Givskov M. The role of quorum sensing in the pathogenicity of the cunning aggressor Pseudomonas aeruginosa. Anal Bioanal Chem 2007; 387: 409-414.

57 Givskov M. Jamming the command language of bacteria: a new approach to the control of bacterial infections [Doctoral Thesis]: Danish Technical University, 2005.

58 El-Azizi MA, Starks SE, Khardori N. Interactions of Candida albicans with other Candida spp. and bacteria in the biofilms. J Appl Microbiol 2004; 96: 1067-1073.

59 Hogan DA, Kolter R. Pseudomonas-Candida interactions: an ecological role for virulence factors. Science 2002; 296: 2229-2232.

60 Pierce GE. Pseudomonas aeruginosa, Candida albicans and device-related nosocomial infections: implications, trends, and potential approaches for control. J Ind Microbiol Biotechnol 2005; 32: 309-318.

61 Ramage G, Saville SP, Wickes BL, López-Ribot JL. Inhibition of Candida albicans biofilm formation by farnesol, a quorumsensing molecule. Appl Environ Microbiol 2002; 68: 54595463.

62 Jensen PØ, Bjarnsholt T, Phipps R, et al. Rapid necrotic killing of polymorphonuclear leukocytes is caused by quorumsensing-controlled production of rhamnolipid by Pseudomonas aeruginosa. Microbiology 2007; 153: 1329-1338.

63 Davies DG, Parsek MR, Pearson JP, et al. The involvement of cell-to-cell signals in the development of a bacterial biofilm. Science 1998; 280: 295-298.

64 Bjarnsholt T, Jensen PØ, Rasmussen TB, et al. Garlic blocks quorum sensing and promotes rapid clearing of pulmonary Pseudomonas aeruginosa infections. Microbiology 2005; 151: 3873-3880.

65 Bjarnsholt T, Jensen PØ, Burmølle M, et al. Pseudomonas aeruginosa tolerance to tobramycin, hydrogen peroxide and polymorphonuclear leukocytes is quorum-sensing dependent. Microbiology 2005; 151: 373-383.

66 Givskov M, de Nys R, Manefield M, et al. Eukaryotic interference with homoserine lactone mediated procaryotic signalling. J Bacteriol 1996; 178: 6618-6622.

67 Rasmussen TB, Bjarnsholt T, Skindersoe ME, et al. Screening for quorum sensing inhibitors (QSI) by use of a novel genetic system, the QSI selector. J Bacteriol 2005; 187: 1799-1814.
68 Hentzer $\mathrm{M}, \mathrm{Wu} \mathrm{H}$, Andersen JB, et al. Attenuation of Pseudomonas aeruginosa virulence by quorum sensing inhibitors. EMBO J 2003; 22: 3803-3815.

$69 \mathrm{Wu} \mathrm{H}$, Song ZJ, Hentzer M, et al. Detection of N-acylhomoserine lactones in lung tissues of mice infected with Pseudomonas aeruginosa. Microbiology 2000; 146: 24812493.

70 Singh PK, Schaefer AL, Parsek MR, et al. Quorum-sensing signals indicate that cystic fibrosis lungs are infected with bacterial biofilms. Nature 2000; 407: 762-764.

71 Hentzer M, Givskov M. Pharmacological inhibition of quorum sensing for the treatment of chronic bacterial infections. J Clin Invest 2003; 112: 1300-1307.

72 Skindersoe ME, Alhede M, Phipps R, et al. Effects of antibiotics on quorum sensing in Pseudomonas aeruginosa. Antimicrob Agents Chemother 2008; 52: 3548-3663.

73 Wolter J, Seeney S, Bell S, et al. Effect of long term treatment with azithromycin on disease parameters in cystic fibrosis: a randomized trial. Thorax 2002; 57: 212-216.

74 Equi A, BalfourLynn IM, Bush A, Rosenthal M. Long term azithromycin in children with cystic fibrosis: a randomised, placebo-controlled crossover trial. Lancet 2002; 360: 978 984.

75 Tramper-Stranders GA, Wolfs TF, Fleer A, Kimpen JL, van der Ent CK. Maintenance azithromycin treatment in pediatric patients with cystic fibrosis. Long-term outcomes related to macrolide resistance and pulmonary function. Pediatr Infect Dis J 2007; 26: 8-12.

76 Smyth AR, Cifelli PM, Ortori CA, et al. Garlic as an inhibitor of Pseudomonas aeruginosa quorum sensing in cystic fibrosis - a pilot randomized controlled trial. Pediatr Pulmonol 2010; 45: 356-362.

77 Lee B, Haagensen JAJ, Ciofu O, et al. Heterogeneity of biofilms formed by non-mucoid Pseudomonas aeruginosa isolates from patients with cystic fibrosis. J Clin Microbiol 2005; 43: 5247-5255.

78 Ciofu O, Mandsberg LF, Bjarnsholt T, Wassermann T, Høiby N. Genetic adaptation of $P$. aeruginosa during chronic lung infection of patients with cystic fibrosis: strong and weak mutators with heterogenous genetic backgrounds emerge in mucA and/or lasR mutants. Microbiology 2010; 156: 1108 1119.

79 Costerton JW, Stewart PS, Greenberg EP. Bacterial biofilms a common cause of persistent infections. Science 1999; 284: 1318-1322.

80 Reid G. Biofilms in infectious disease and on medical devices. Int J Antimicrob Agents 1999; 11: 223-226.

81 Tolker-Nielsen T, Høiby N. Extracellular DNA and F-actin as targets in anti-biofilm CF therapy. Future Microbiol 2009; 4: $645-647$ 